\title{
Misperceptions of Climate Change Damage Coastal Tourism: Case Study of Byron Bay, Australia
}

Ralf Buckley

Tel +61 75552 8675, Fax +61 75552 8895, Email r.buckley@ griffith.edu.au

Professor Ralf Buckley is Director, International Centre for Ecotourism Research, Griffith University, Gold Coast Australia (www.gu.edu.au/centre.icer); former Chair, Environment Advisory Board, Gold Coast City Council; and a long-term ratepayer and resident at Byron Bay. His $\mathrm{PhD}$ (ANU, 1978) is in ecology. His research interests include ecology and impact assessment, environmental planning and management, and links between tourism and environment. 


\title{
Misperceptions of Climate Change Damage Coastal Tourism: \\ Case Study of Byron Bay, Australia
}

\begin{abstract}
Local politics at Byron Bay on Australia's east coast have led to misunderstanding and misrepresentation of the likely effects of climate change on sealevel and coastal erosion. A voting bloc of self-proclaimed "green" members of the local government authority (LGA) has adopted policies and planning instruments which have affected tourism by: placing severe and irrational restrictions on development of residential and holiday accommodation; reducing the opportunities for holiday letting; increasing rates and costs for businesses which provide services to tourists; and creating community division and dissent which drives away higher-yield family tourists. This is occurring even though the LGA acknowledges the town's dependence on tourism.
\end{abstract}

The key issue is that the LGA has prevented beachfront landowners from protecting their own properties against erosion which the LGA now claims, incorrectly, to be due to climate change but which is in fact caused by a groyne built to protect facilities owned or managed by the LGA itself. Addressing this erosion is completely straightforward from a technical perspective, but is prevented by political powerplays. Through this political mechanism, misperceptions of climate change have hence damaged the town's tourism industry and investment, which have moved to neighbouring local government areas.

\section{Introduction}

It is only very recently that government planning and policy agencies have begun to take into account the potential effects of climate change. In many countries, national government agencies with a scientific mandate and trained staff continue to contribute to understanding of climate change mechanisms and effects. Local government bodies, however, do not necessarily have either the skills or the will to make accurate assessments of relevant scientific information and convert it into appropriate plans and actions. In addition, they may be driven by local political agendas which either ignore such information or misuse it for unrelated purposes. 
Here I describe such a case from a small tourism-dependent and politically peculiar coastal town in eastern Australia. In contrast to similar neighbouring towns and local government areas, a nominally green voting bloc in the local government authority (LGA) at Byron Bay has consistently and insistently acted against available evidence on climate change and related processes, and in the process has caused significant social and economic damage to the tourism industry and investment.

The analysis starts by outlining climate change issues for coastal tourism, as compared to mountain tourism which has been studied more frequently in this context. It describes the case study site of Byron Bay and compares it with the Gold Coast, a neighbouring tourist town which has taken a very different approach. Byron's political and socio-economic history, and its current dependence on tourism and amenity migration, are outlined briefly. Actual climate change and sealevel projections, and the effects of various existing engineering works, are summarised. These provide a context in which the policies and planning instruments adopted by the local government authority are reviewed. Finally, the consequent outcomes for tourism and investment are reported.

This approach may be considered as a political ecology perspective (Forsyth, 2003), albeit at a rather primitive level. It follows the basic methodological principles of political ecology (Gössling, 2003), tracing a "history of narratives" (Scott and Sullivan, 2000) in order to examine how "power and politics shape human environment relationships" (Robbins, 2004; Roth, 2006), including "actors' interests and ideologies" (Gössling, 2003). It differs, however, from some of these broader-scale analyses in that for this particular case study, the politics are rather local; they influence local interpretations of national or global scientific research, but have rather little effect on its conduct or publication. In addition, the focus here is on how political debates over human-environment relationships have affected tourism, which is a part of the local political debate but distinct from science.

As with any attempt to trace narratives and interpret interests and ideologies, information sources are imperfect. I have not attempted to incorporate any analysis of individual motivations, questions of professional pride or personal pigheadedness, kinship or shared religious beliefs, opportunities for profit or career advancement. I have relied solely on published documents, ranging from top-tier academic journals to letters to local newspapers, consultant reports to council minutes. This may produce a degree of asymmetry in information available for different actors. Individuals, or representatives of community or 
industry groups can write rather freely to local newspapers, expressing quite unbridled opinions. Local government Councillors also make their opinions known through letters and quotations in editorials. The deliberations of both local and State Governments as corporate bodies, however, are rather more secret. Byron Shire Council meeting agendas and minutes are available on its website, but many of the more critical items are considered as confidential and are debated only in closed session, inaccessible to public observers. The State Government has many different agencies and they do not necessarily act in concert. Individual staff may also have considerable latitude in their opinions and actions, so these are not necessarily representative of the State Government's official view at any given time.

This analysis does not present any definitive conclusion as to why individual stakeholders have acted in any particular way. Rather, it argues that science has been misinterpreted rather severely for political ends, with significant negative consequences for tourism.

The political manoeuvring described in this case study is continuing as this article is submitted. Irrespective of the outcome, the tourism industry has already been damaged by the adverse publicity. This may provide an object lesson for other tourism destinations. It seems unlikely that the current LGA at Byron will change its views; but it is quite likely that it will be overruled or removed by the State Government of NSW, or that its internal balance of power will change at the next local election.

\section{Reactions to Climate Change: Coastal cf. Mountain Tourism}

When public knowledge of global warming first became widespread, the first sector of the tourism industry to respond was the ski resorts. Essentially, these resorts denied and suppressed any mention of rising snowlines, shortening seasons or deteriorating snow quality until they had successfully repositioned themselves as mountain resort-residential developments where the corporate bottom-line depends much more on real estate sales, holiday retail shopping and summer golf than on winter ski-lift tickets.

Most coastal tourism destinations, in contrast, seem to have remained remarkably blasé about rising sealevels, even though these are one of the best-documented aspects of global change. There are several likely reasons. First, global average sealevel rise to date during historical times has been a few millimetres, whereas most coastal regions experience daily tidal ranges 
of several metres, so the significance of sealevel rise may not yet have been appreciated. Secondly, the opportunities to compensate for reduced natural snowfall, for example through artificial cloud seeding, snowmaking machinery, and/or snow grooming, are rather limited. Techniques to protect coastal property against sealevel rise, in contrast, are essentially the same as those used to provide protection against coastal erosion and are thus well-established and well-tested, and likely to be highly effective within the predicted range of sealevel rise over the planning horizons of landowners and local governments. Some of these approaches, such as rock walls, groynes and sand-pumping schemes, can be quite expensive, but beachfront property in coastal tourist towns is sufficiently valuable to justify the investment. Property is also expensive in mountain resorts, but land and buildings are not generally at any direct risk from climate change, and there is not much that an individual property owner can do to counteract reduced snowfall.

Another difference between coasts and mountains is that most coastal tourist towns have a multitude of different individual landowners, and a local government responsible for planning and infrastructure. There is perhaps a perception, albeit often an erroneous one, that only the absolute oceanfront blocks are at any potential risk from sealevel rise, leaving property values elsewhere unaffected; and that if any infrastructure were to be at risk, the local government would take any steps necessary to protect it. Many mountain resorts, in contrast, are largely owned by a single corporation, so if visitor numbers or land values fell, that company would be affected directly. This pattern is by no means universal, however. There are many coastal resort-residential developments owned by a single corporation in the same way as mountain resorts; and there are many mountain tourist towns with a local government and individual property ownership. And, of course, many towns popular with tourists, in either coastal or mountain regions, have diversified economies in which tourism plays only a relatively small role.

\section{Australian Coastal Tourist Towns: Gold Coast and Byron Bay}

Coastal tourist destinations are certainly not ignoring climate change and projected sealevel rise. In general, they are considering it carefully, and concluding that it is currently quite manageable. To take one example, one of the principal tourist towns in Australia is the Gold Coast in southern Queensland. The city centre is built on the coastal plain of the Nerang River, with high-rise hotels, apartment buildings and office blocks built along the 
riverbanks, the coastal foredunes and the former swamps and sandflats in between. There is private residential housing right along the oceanfront and also along a vast complex of canal estates cut out of the low-lying sediments. The high-rises are not at risk because they are built on pilings driven deep into the sediments far below sea level. The coastal houses are not at risk because they are protected by rock walls constructed underneath the coastal foredune. The recreational amenity of the beach is already protected by a large-scale sand-pumping scheme which can reshape it if needed (Gold Coast City Council, 2006). The only area of immediate concern is the canal estates, which are often built barely above high tide level. It is only when king tides coincide with a set-up from storm swells, however, that these highest water levels are reached in the canal estates. According to Council staff, it would be feasible to install a system of tide-gates to provide protection against these peak water levels, whilst still allowing boat access at other times. Even though the physical geography of the Gold Coast puts it potentially at risk from sealevel rise, therefore, its human geography allows it to address that risk without difficulty, at least in the short term.

The Gold Coast lies right on the southern border of Queensland, and indeed the city continues across the border into Tweed Shire in the neighbouring State of New South Wales. Immediately south of Tweed is Byron Shire, which includes the coastal tourist town of Byron Bay. In contrast to the Tweed and Gold Coast areas, and indeed other coastal shires further south, the local government at Byron has taken an almost panic-stricken and highly politicised approach to potential sealevel rise. In the process, it has caused damage to its tourism industry and its property values, undermining the town's major source of employment and the Council's own rate base. This panic appears to be driven by a peculiar political ideology which encourages major misperceptions of coastal processes and global climate change. In this case study, I attempt to analyse how such a state of affairs has arisen, and what its consequences might be. This is far from straightforward. Indeed, the approaches taken to coastal erosion, conservation and global change in Byron Bay are so far at variance with commonsense that they appear quite incomprehensible. It is only through an essentially political analysis that one can propose any reasonably plausible understanding of the various dealings and debates to date - some apparently well-meaning but severely misguided, and others perhaps more underhanded. 


\section{Geography, History and Society}

Byron Bay is a small coastal town in northern New South Wales (Byron Shire Council, 2006). The town centre is immediately north of Cape Byron, the easternmost point in mainland Australia. The suburbs of Byron Bay stretch both south and west of the Cape, as well as north. The local government area also includes the coastal settlements of New Brighton and Ocean Shores further north, and the inland rural township of Mullumbimby, set amidst farmland and acreage residential properties. Historically, Byron Bay was a centre for Australia's east-coast whaling industry, and subsequently a small regional centre in a rather depressed agricultural area. In the early 1970s it became somewhat of a centre for hippy lifestyles in Australia, along with nearby Nimbin and in parallel with Cedar Bay much further north on Cape York.

During this period, and indeed the following decade, there were some major conservation battles over the logging of rainforest and old-growth eucalypt forest in and around what is now Nightcap National Park, part of the Central Eastern Rainforest Reserves Australia World Heritage Area and a little inland from Byron Bay (Australia, Department of Environment and Heritage, 2006). Some of Byron's older current residents, young and newly-arrived hippies at the time, played a significant part in protecting these forests, in re-establishing Byron as a desirable place to live, and in starting a small-scale economy including crafts, organic food production and so on. Not surprisingly, these longer-term residents seem to have a strong feeling of ownership for the Byron area, and hence a certain degree of possessiveness, even though many of them now make a living from tourists and more recent migrants. There is also a much younger sector of society in the broader Byron area which sees itself, perhaps, as the successors to the earlier environmental activists. There are the so-called ferals, there are Rainbow People, and there are devotees of various new-age philosophies.

Many Byron residents belong to national or international environmental organisations. There are also several active local conservation groups. Some of these are engaged in effective on-ground restoration work. Others, however, are engaged principally in local political activism, apparently focussed more on social issues that conservation of the natural environment. Most vocal of these is BEACON, the Byron Environmental and Conservation Organisation. This is the Byron analogue of the Gold Coast's GECKO, the Gold Coast and Hinterland Conservation Organisation (2006). GECKO has been highly effective in identifying local planning and development issues of national conservation significance, 
making good use of scientific and technical information, and lobbying at all levels of government or to protect remnant ecosystems of high conservation value within the Gold Coast area. As outlined below, however, BEACON has taken a very different approach, particularly in regard to climate change. Membership appears to be rather small. Minutes of an Annual General Meeting (BEACON, 2004) indicate that there are about 20 members. Both the Mayor and Deputy Mayor of the Shire, the local leader of the Green Party, and the deputy editor of one local newspaper, however, were recorded as present at that meeting, so it has political influence greatly disproportionate to its size.

By far the bulk of Byron's current residents are no different from the rest of suburban Australia. Their houses, cars, jobs, schools, supermarkets, shops, food and clothing are not significantly different from counterparts up and down east-coast Australia, or indeed many other areas. There is an industrial estate and a small light manufacturing sector, but most jobs are in the service sectors, including construction, property sales, rental management, tourism, retail, education, music and arts. Byron may have more than its share of clairvoyants, chiropractors and astral healers; but it also has a standard complement of cafes and chartered accountants, clothing and hardware stores, car yards and council workers, police and hospitals, pubs and hotels.

In fact, there are rather few hotels (Byron Bay Online, 2006). Tourist accommodation is in short supply (Chigwidden, 2006a) and high demand. Most tourist accommodation is in holiday lodges or in private houses and apartments which are furnished and let specifically for holiday visitors, during at least part of the year. Some of these houses are occupied by their owners for most of the year, and let only during peak periods, when the owners leave town so as to profit from the high rental rates available. Others are owned by people who live and work elsewhere, who hope to move to Byron once they have the opportunity, and who rent their houses out to holidaymakers meanwhile so as to offset rates, mortgages and maintenance costs. A few of these landowners are quite wealthy, which appears to provoke envy from other residents. In reality, however, the Byron economy and its Council are in part sustained and indeed subsidised by landowners who earn their income elsewhere and are hence able to provide both the capital investment upon which tourism depends, and the rates which fund the town's entire infrastructure. And the majority of residential housing at Byron Bay, as elsewhere, is not only owner-occupied, but represents "the superannuation and retirement funds for their owners who may have no other assets" (Hall, 2006a). 


\section{Tourism and Amenity}

Byron Bay receives 1.7 million tourists every year, and its economy is very heavily dependent upon tourism. Byron has around 50,000 residents and 13,000 ratepayers, so it has over 120 tourists for every ratepayer (Byron Shire Council, 2006). In the 1970s, tourism was put forward as an alternative to agricultural production and processing industries, and so it has in fact proved. Many residents and even local-government Councillors have argued that they do not want Byron Bay to become a tourist town, even though it already is. In particular, they seems to resent any comparison to Queensland's Gold Coast, their much larger northern neighbour. Byron businesses which depend on tourism, of course, have a very different perception, and this has lead to acrimonious exchanges in local newspapers, examined further below.

There is a perception that Byron Bay is a backpacker destination (Westerhausen and Macbeth, 2003), and so indeed it is; but not solely so. It does indeed have a reputation as a party town (Anon, 2006a), but the backpacker and daytripper market makes up only one component of the tourism industry as a whole. Many visitors to Byron Bay, and indeed perhaps most, are families who rent a holiday house or apartment for a week or a month, at quite considerable cost. There are beachfront houses, for example, where rents range up to $\$ 7,000$ per week in peak periods. Indeed, there are public caravan parks whose cabins are apparently rented at over $\$ 1,400$ per week (Heilpern, 2006).

Byron Bay also has a number of rather high-profile citizens, notably various actors and film producers, who have helped to publicise the area as a popular place to live. As a result, it has become a popular destination for amenity migration, part of Australia's so-called sea-change phenomenon (Burnley and Murphy 2003). The current Byron Shire Council, however, has

placed very severe restrictions on residential development, apparently because of a combination of infrastructure and ideology, and this has pushed up prices on existing residential land and housing. As in many other tourist destinations, tourism development and amenity migration are closely linked, with the construction industry, the retail sector and indeed social changes driven jointly by both. As elsewhere (Johnson, 2003), tourism perhaps provides a transition between an economy dependent on agriculture, and one dependent on information. People who make their living from their creative or analytical skills, whether sculptors or stockbrokers, authors or accountants, no longer need to live in the metropolis. 
Thanks to the World Wide Web, they can practice their professions equally well in Byron or Banff as in Sydney or San Francisco.

\section{Climate Change and Environment at Byron}

Byron Shire lies in a biologically diverse area, the Macleay-MacPherson Overlap Zone where the heath and eucalypt forests of the south meet the tropical and subtropical rainforests of the north (Burbidge, 1960). The CERRA World Heritage Area comprises a number of individual national parks separated by farmland, and several of these parks contain small peaks or scarps with very localised flora and fauna, some of them endangered. From a conservation viewpoint, the principal risk from climate change in the Byron region is likely to be the extinction of particular species: both directly, as their climatic envelope moves; and through a variety of indirect ecological mechanisms involving interspecies competition, energetics, reproduction and so on. None of these are particularly tied to tourism, but one might expect that they would be causing concern for environmental groups.

Similarly, if sealevel rises as predicted by the Intergovernmental Panel on Climate Change (IPCC, 2007), the principal risks to biological diversity would be in estuarine areas and so-called ICOLLs, intermittently closing and opening lakes and lagoons, where plant and animal distributions are very tightly tied to particular tidal zones. Even if open beaches were to erode, the main conservation concern would not be for the creatures of the sandy beaches themselves, but for those of littoral heaths and forests on sandy terrestrial coastal landforms. If these landforms erode, their particular ecosystems have nowhere to move to, because adjacent areas inland are cleared for agriculture and in any event have different soils and groundwater.

\section{Coastal Processes and Dynamics}

Relevant scientific and technical information falls into two main categories: climate change, and coastal processes. Each of these categories includes information at widely different spatial scales, from global mean trends to a single beachfront block. In addition, each contains data with different levels of uncertainty: particularly as regards future predictions I comparison to past trends. Public discussion of these issues, however, has tended to confuse 
these categories and issues. Information has commonly been presented in a selective or mistaken manner, either intentionally or inadvertently.

There are three separate sets of information which need to be appreciated independently before their possible interactions can be examined. These are: (1) past and present geomorphological processes which have shaped the current coastline and continue to drive its day-to-day dynamics; (2) the effects of engineering works which have been, or might be, carried out at various times; and (3) likely scenarios for future sealevel rise and wave climate shifts over various time scales. Those are considered in turn below.

There are several different beaches of different sizes, types and shapes within Byron Shire, but the critical one is a so-called zeta beach, a hook-shaped beach running north from Cape Byron to Belongil Spit and beyond. Beaches of this shape are commonplace along the eastern Australian seaboard (Short, 1999), where there is a gradual northward drift of nearshore sand and sediment driven by wave action, tidal patterns and large-scale currents. During southerly storms, slugs of sand are pushed around Cape Byron. Some of this sand is lost off the continental slope, some migrates slowly across the bay, and some ends up on the beaches in Byron Bay (Goodwin, 2006). It then moves north along the beach and nearshore zone, but since these are protected by the headlands, the movement is gradual. During the much less common northerly storms, some of the sand can be pushed back into the hook of the bay, changing the alignment of the beach (Goodwin, 2006), but the overall drift is northerly.

Where a river runs out to the ocean on these sandy shorelines, this northward drift creates a gradually elongating sandspit which blocks the river and deflects it north, running along behind the spit before it finally reaches the sea. During floods, the river can breach the base of the spit and regain its direct ocean access. Belongil Creek is one such river, albeit a small one.

Aerial photographs or satellite images of the Belongil area show a series of ridges parallel to the current coastline. These are accretion ridges, and indicate that the beach has grown outward during recent geological times, with sand gradually filling up the bay. In terms of its overall geology, therefore, Belongil Beach is a stable shoreline, fixed in place by Cape Byron and subject only to small oscillations associated with storm patterns and, in the absence of any engineering works, potential shifts in the position of the rivermouth. 
There is a political perspective even to the scientific information on coastal change at Belongil. Byron Shire Council has relied both directly, and indirectly through its consultants WBM Oceanics (2003), on reports produced three decades ago by the NSW State Government (Gordon et al., 1978; Roy et al., 1978). These reports were sponsored by a former section of the NSW State Government which might well be held responsible for downdrift erosion caused by an artificial headland built in the Byron Bay town centre, described below. The authors of those reports have also exercised more recent political influence through the subsequently-formed NSW Coastal Council, and through the Peer Review Panel (Watson, 2003a,b,c) for the Byron Coastal Management Study (WBM Oceanics, 2003).

Whether coincidentally or otherwise, Byron Shire Council seems to have taken a deliberate decision to ignore more recent and detailed scientific studies which reach different conclusions (Goodwin, 2005; Goodwin et al., 2006). Indeed, I was present at a Byron Shire Council meeting where one "green" Councillor said "No more science". At the same time, however, the same Councillor argued that Council should plan on the basis of the most recent, untested and unpublished predictions for sea-level rise.

The most detailed and up-to-date information currently available on coastal processes at Belongil (Goodwin, 2006) indicates that the Belongil shoreline was growing outward almost continuously from 1000 years ago until 50 years ago. This growth continued even during the period from 1884 to 1960 when sealevel had already started to rise. Indeed, during that period the Belongil Beach grew outwards by about 30-40-m horizontally, even though mean sea level rose about $0.1 \mathrm{~m}$ vertically. Since the $1960 \mathrm{~s}$ the Belongil Beach has suffered erosion. This, however, is due principally to engineering works as below (Goodwin, 2006).

\section{Engineering Works and Impacts}

There are three sets of engineering works which may affect the dynamics of the beach to different degrees. By far the most influential is an artificial headland in the centre of Byron township, at the southern end of Belongil Beach. This is a large, steep-walled solid rock structure which protrudes some 50 metres into the bay, tipped by a rock groyne at right angles to the beach and protruding a further 35 metres. Built to protect public and private 
land and buildings in the centre of the town, and also used to provide carparking, it has had a significant effect on the beach profile to the north. This effect is readily visible on aerial photographs or satellite images, even low-resolution images such as those in Google® Earth®.

Viewed from above, there is a clearly visible step in the otherwise smooth outline of the beach. On the southeastern, updrift side of the artificial headland and groyne, the beach is further seaward than would otherwise be the case, as sand is trapped on the updrift side. On the northwestern, downdrift side the beach is further inland than would otherwise be the case, because the supply of sand from the south is interrupted by the artificial headland. Now that the updrift beach has grown outwards to the tip of the headland, sand does drift past it once more, but in a nearshore bar rather than along the beach. This effect is greatest immediately adjacent to the northern side of the artificial headland, and decreases northward until the nearshore bar rejoins the beach, and the beach regains the shape it would have if the headland were not present. Such effects are commonplace where shore-normal groynes are built on sandy beaches with a unidirectional longitudinal drift. According to the most detailed and up-to-date analyses currently available (Goodwin, 2006), the artificial headland has caused Belongil Beach to erode 30-35 m horizontally.

The second major engineering feature is that many sections of Belongil Beach have rock walls at or above high tide mark which run longitudinally, parallel to the beach. These walls have been built at different times over past decades because of concerns over potential risk of storm erosion to foredunes. Especially in the southern part of Belongil Beach, this risk increased greatly as a result of beach erosion caused by the artificial headland and groyne described above, and it appears that many of these walls were built during the period when the beach profile was adjusting to the effects of the newly emplaced headland. At least some, however, seem to be remnants of a former whaling jetty. The walls in the southern section of Belongil Beach are gently-sloping, permeable boulder piles which start either around or above the current high tide mark. Some of them are on private land; some on a former road reserve which is now largely beach; and some cross between the two.

These walls do not cause beach erosion, for two reasons. Firstly, they are at or above the upper end of the normal tidal range, so the ocean only reaches them occasionally. As noted by Thom (2003) for a comparable beach further south on the same coastline: "At localities such as Bondi, well-designed and located walls have not seriously interfered with beach 
amenity since construction in the 1920s". Secondly, they are permeable, and do not reflect incoming waves. Swash passes between the boulders, carrying sand in both directions. Indeed, the walls reduce the velocity of outgoing swash, reducing erosion. This is the same principle as that used to reduce erosion in stormwater drains, and is the reason the walls were built in the first place. Their effect is thus quite different from that of the artificial headland, which protrudes below low tide, and is built with steep solid walls which reflect incoming waves.

The third engineering feature is the suburb of Belongil, which stretches from the beachfront blocks back to the creek and would be at risk of flooding if the foredune were breached or water level in the creek rose significantly. Debate to date has focussed on the oceanfront properties, which face potential wave erosion during storms; but in fact most of the oceanfront houses are set high on a foredune, whereas the suburb behind is set much lower and could be flooded quite quickly.

\section{Sealevel Projections and Coastal Change}

There are several separate scientific and social questions to consider when examining past and potential changes in sea levels. Correspondence in local Byron Bay newspapers considered further below, indicates a considerable level of confusion between these issues, amongst local stakeholders.

At a broad scale we can distinguish at least eight different issues:

- $\quad$ Physical mechanisms driving past and present climate change at global scale.

- Human impacts on global climate change and how to reduce or ameliorate them.

- $\quad$ Physical mechanisms driving changes in sea level at global scale.

- $\quad$ Physical mechanisms, including sealevel changes, driving changes in coastlines.

- $\quad$ Past and predicted changes in relative sea level at regional scales.

- $\quad$ Possible sudden or large-scale changes in climate and sea level due to human impacts and threshold-type natural processes.

- $\quad$ Past and predicted changes in coastlines and coastal processes at local scale.

- Human responses to such local-scale physical changes. 
Some of the public commentary at Byron Bay, for example, has discussed human response to potential local beach erosion in the same terms as human actions to minimise greenhouse gas emissions, when these are in fact at opposite ends of a long chain of cause and effect. Similarly, some public comments have failed to distinguish between possible threshold-type physical changes, which could have potentially disastrous consequences for current human civilisations, but are relatively unlikely; and continuing small-scale gradual physical changes, which are very likely but have manageable consequences.

From a tourism perspective the critical issue is urban planning in relation to coastal change, if any, in the recent past and near future (Walsh et al., 2004). If large sections of the Greenland icecap and Antarctic ice shelves were to melt or collapse suddenly, the global consequences for human civilisations could well be extremely severe. Over 100 million people live within $1 \mathrm{~m}$ of high tide (Zhang et al., 2004) and major iceshelf collapse could raise sealevel by many times that amount. But that is not currently considered likely (IPCC, 2007); and if it were to occur, it would jeopardise nations worldwide, not just residential housing and tourism development at Byron Bay. Local government planning cannot realistically address such an eventuality. It can indeed consider the much more gradual trends predicted by the IPCC (2007). For this, however, the critical issue is local coastal processes in relation to regional sealevel projections, regional wave climate and sand supply, and local engineering works all of which produce effects at similar and very much smaller scales (Goodwin, 2005, 2006). Below, therefore, I summarise relevant evidence as it relates to the sandy coastlines of northern New South Wales, and Belongil Beach in particular.

The Fourth Assessment Report of the Intergovernmental Panel on Climate Change, the peak international scientific body responsible for climate change projections, was released for public comment in the USA early in 2006 (IPCC, 2007), and in practice is available worldwide. The report reviews the most up-to-date scientific information on past, present and potential rates of relative sealevel rise, with global maps showing individual contributing factors (Miller and Douglas, 2006; Overpeck et al., 2006) and the overall outcome.

The global average rise in relative sealevel over the past few decades has been around 1.9 $\mathrm{mm}$ per year. In different parts of the world, rates over the past 50 years range from minus $0.4 \mathrm{~mm}$ to plus $3.6 \mathrm{~mm}$ per year (IPCC, 2007). Over the past decade, satellite altimetry measurements indicate rates ranging from minus 15 to plus $15 \mathrm{~mm}$ per year in different parts of the world. Short-term fluctuations may be as much as $100 \mathrm{~mm}$ or even more in a single 
year. That is, the short-term fluctuations far outweigh the long-term trends. In geological time, sealevels have sometimes risen by rates of up to $30 \mathrm{~mm}$ per year. That is, the current maximum rates, presumed due to human influences on global climate, are within the range of rates due to purely natural processes.

For the Byron Bay area the predicted rise during the next century is about $20-30 \mathrm{~cm}$. This is not something to ignore, but nor is it something to panic about. Tides at Byron go up and down a metre each day. In some parts of the world, the tides are 10 metres or more. Surf on Byron's beaches is often up to a couple of metres high. Again, in some places around the world, the surf can be ten times larger than this and hundreds of times more powerful. Such areas still support coastal towns with structures built to withstand prevailing conditions.

To predict how coastlines might change with climate, the best evidence derives from the recent geological past. For much of the past few hundred thousand years, global sealevel has been considerably lower than at present, but there was a period a few thousand years ago when sea level along eastcoast Australia was a metre or two higher than it is now (Haworth et al., 2002). Raised sealevels affect coastlines in many different ways. On sandy coastlines, the combination of sealevel rise and storms changes the configuration of spits, bars and beaches. In estuarine areas, effects are more complex still, as river flow regimes may also change. If ocean temperatures rise, coral reefs could grow further south, so more of the mainland shoreline would be protected against storms and surf. If the sealevel rises faster than coral reefs can grow, however, then tropical shorelines would lose their protection against ocean swells.

Overall, therefore, risks at Byron Bay are relatively low in comparison with other parts of the world. Relative sealevel rise is less than $2 \mathrm{~mm}$ per year, according to the IPCC (2007) maps. Other parts of the world will feel the pressure long before Byron. Byron's tidal range is small, and wave energy relatively low. It has a continuing supply of sediment through northward drift along the eastern Australian seaboard. And perhaps most importantly, the Byron area has several major headlands, including Cape Byron itself, which will hold the shoreline close to its current position.

The principal current risks to the Byron coastline are not from sealevel rise, or even a shifting of cyclone belts, but from the possibility of several major storms in quick succession. The probability of this may change in future (Witze, 2006); but currently it is no different than 50 
years ago, no different at Byron than anywhere else on central east-coast Australia, and much lower at Byron than many other parts of the world.

\section{Perceptions and Politics}

Even though possible erosion of open sandy beaches is, in reality, a relatively minor and manageable outcome of potential climate change, most of the public and political debate about global change in Byron has been focussed almost exclusively on this possibility. Few commentators (eg Pugh, 2006) have paid attention to estuarine ecosystems, and none, apparently, to forests inland. The reason for this seems to be historical. There have been arguments over beach erosion in the past, unrelated to climate change, and these have simply been rephrased. Essentially, proponents of a particular political view in regard to coastal management have seized upon sealevel rise as a new justification for their position, even though likely sealevel rise does not actually justify that position, and even though their position was adopted before information on likely sealevel rise became generally available.

Some of the letters, articles and paid advertisements in local newspapers, relating to sealevel rise, are so misleading that they could only be described as scaremongering. The local Federal Member of Parliament, for example, who is a member of the Federal Opposition, took out a paid advertisement in the Byron newspapers with a full-page fake photograph of seawater flooding one of Byron's main tourist streets, which is many metres above current sea level. The text of the advertisement was a criticism of the current Federal Government leader for Australia's failure to ratify the Kyoto Agreement on climate change. The Prime Minister, however, is unlikely to read local Byron Bay newspapers. Presumably, therefore, the advertisement was targeted purely at local prospects for re-election; especially since this was the most closely-contested electorate in the last Federal election, with a former sitting candidate ousted by only a couple of hundred votes. For most of the people who saw this advertisement, sandwiched between the sporting news and the supermarket specials, the strong - but erroneous - visual message was that the Byron CBD will soon be flooded by rising sealevel.

One of the local newspapers also published a short article by the president of local environment group BEACON (Pugh, 2006) including the statement that sealevel would rise over 70 metres when the Antarctic icecap melted. Nothing in the article indicated that since 
the Antarctic icecap is raised on rock and not in thermal contact with the ocean, it would take far greater warming to melt the icecap than it does to affect the ice shelves, which are floating on the ocean.

\section{Planning Instruments and Policies}

In most local government areas, town planning is perceived principally as a technical process to be carried out by professional staff planners. The role of elected Councillors is generally seen as large-scale strategy, broad oversight, and a direct involvement only for large proposals which would effectively alter these strategic directions. In Byron, however, planning has become a highly politicised process, with even the smallest of proposals subject to consideration by the full Council. The current Council has 10 elected Councillors, including the Mayor. In Australia, local governments exercise their power solely by delegation from State Governments, through specific enabling legislation. In general, party politics are confined to Federal and State elections, and local governments deal only with local issues. Indeed, a recent Inquiry by the Crime and Misconduct Commission of Queensland (2006) has lead to certain incumbent Councillors, and external interests, facing Court charges for having, allegedly, established an undeclared campaign fund intended to promote the election of a pro-development bloc of candidates.

In Byron, four of the incumbent Councillors apparently see themselves essentially as a local-government "green" or "progressive" bloc (Patterson, 2006a). They would be a minority, except that the Mayor subscribes to the same philosophy, and is permitted two votes: one as a Councillor, and a casting vote as Mayor, which she uses routinely, in the event of a division along political lines, to override the votes of the five other Councillors who would otherwise constitute a majority (Thalmaan, 2006a).

Even this might not present a problem for either tourism or local residents, if the green bloc and the Mayor were pursuing policies, and adopting planning instruments, which addressed the more urgent and significant ecological issues in the Shire. In practice, however, this is by no means the case. Rather, the supposedly green bloc has pursued a highly ideological political agenda which focuses almost entirely on social rather than environmental goals. Indeed, it would not be an exaggeration to describe it as attempted social engineering. The term "sociocultural cleansing" has been used in at least one letter to a local newspaper 
(Cohen, 2006). Byron Shire Council's own local advertising, namely a small colour leaflet listing its achievements for 2004 and 2005, shows a strange kind of Venn diagram on its front cover where ideology is explicitly given the most prominent place, separate to and above sustainability.

Exactly what this ideology is, apparently, is not stated in any publicly available Council documents; perhaps following the dictum that the most influential policies are those which remain unwritten (Boothroyd, 1995). Judging from actions and public pronouncements, however, this ideology would appear to have three major themes. The first of these is a strong opposition to tourism and amenity migration. Despite belated public statements by the Mayor (Anon, 2006b) that Byron does indeed depend upon tourism, enormous difficulties have been placed in the way of any private landholders or proponents proposing any form of tourism accommodation or other tourism infrastructure or activity. New planning instruments, notably a Draft Local Environmental Plan produced during 2006, would place extremely severe constraints on the currently widespread practice of holiday letting, which provides a large proportion of the town's tourist accommodation. It would introduce new zonings which would increase the current restrictions on small-scale oceanfront tourist accommodation or indeed private residential development. These zonings, and existing development plans, are centred on a policy of so-called retreat, ie a quite erroneous perception of coastal erosion processes.

There has also been a long-running legal debate over an application to redevelop a site on the northern side of town, immediately north of Belongil Creek, which has for many years been a small-scale tourist resort. There was at one point, a number of years ago, a proposal to build a Club Med® facility on this site, and this provoked strong opposition from a number of local residents who saw it as a symbol of cultural homogenisation akin to the McDonalds $®$ hamburger chain - which is also opposed with equal vehemence (Byron Bay Online, 2006). There is no real logic to this, since other major retail chains such as the Woolworth's ${ }^{\circledR}$ and IGA® supermarket brands are already represented in Byron, and indeed heavily patronised by all. The IGA® store, opened during 2006, advertised itself in advance, without opposition, as a supermarket "that even surpasses metropolitan standards in size" (Anon, 2006c). The political effect, however, has been that the current tourism redevelopment proposal, by a corporation known as Becton, has received strong opposition from the nominally green bloc within Council. 
Currently, following the recent passage of a new Environmental Planning and Assessment Act (2006) in the NSW State Parliament, the approval authority for major developments such as the Becton proposal, was taken over directly by the State Government Minister of Planning (Anon, 2006d). Following this, the BEACON representative published complaints about the Minister in the local papers, rather than complaints about Becton (Anon, 2006e). Other letters, however, also co-signed by BEACON, praised the Minister for his "foresight and determination" (George et al, 2006). In addition, occasional letters have been published from individual residents, characterising the Minister as a "devil" or "satyr" (Grenfell, 2006). There was apparently also a verbal altercation between one of the "green" Councillors and two Becton staff, leading to legal action by the latter, and an out-of-court settlement (Anon, 2006f). Most recently (September 2006), the Minister has approved the Becton development, with a number of conditions (Chigwidden, 2006a; McDonald, 2006a) but opposition remained (Anon, 2006g), with one local government Councillor referring to the State Government's actions as "bastardry" (Tabart, 2006).

The level of controversy has now risen to the point where a number of residents (Hudson, 2006; Narracott, 2006a) and even Councillors (Anon, 2006h; Chigwidden, 2006b), have raised the possibility that the NSW State Government might dismiss Byron Shire Council and replace it with a State-appointed administrator. This has already happened in neighbouring Tweed Shire and is apparently (Anon, 2006h) under consideration for nearby Kyogle Shire. The NSW State Government has already taken over management of public caravan parks in Byron Shire (Chigwidden, 2006c; Patterson, 2006b). Those were previously run by the Council, but according to the State Government Minister for Lands, quoted by Chigwidden (2006c), under Council management they were offering "a tourism experience far below .... potential". Likewise, according to the relevant tourism industry association, quoted by Patterson (2006b), Council's management was “to the detriment of holiday makers".

Interestingly, letters complaining about Becton, beach erosion or the Minister for Planning, or congratulating Byron Shire Council, seem to be written, almost without exception, by residents from the Hinterland part of the Shire who would not be directly affected at all. Residents within the Byron township, which of course has a strong economic dependence on tourism and amenity migration, generally seem to write letters in favour of holiday letting, tourism development and residential opportunities, in favour of engineering works at Belongil, and critical of the Council. For the 13 such letters published up to August 2006, this pattern is significant at $\mathrm{p}<0.02$ (Fisher's exact test). 
Several letters have noted quite correctly that "Sea level rise is not something we can stop or ignore but in the short to medium term there are solutions..." (Hall, 2006b). A resident from Byron Bay township itself (Dane, 2006) reported that "I was on the [Council] Coastline Management Committee for five years and remember the laughs we had about 'planned retreat'. What a joke!" ... "From all I read and heard over those five years from countless experts, there is one answer ... rock walling the Belongil.” And a letter in May 2006 pointed out, correctly, that: the artificial headland in the town centre does indeed cause erosion; that this is shown by the shape of the "gutter" in the beach, which curves in sharply north of the groyne; that "damage is more severe the closer you are to the groyne and tapers off to be minimal by ... the north of the Belongil;", and that with proper design, shore-parallel seawalls "could allow waves to run up the slope, the water could run out between the rubble but deposit its sand."

\section{Consequences for Tourism}

Relatively few tourism destinations worldwide have such iconic status that they can continue to attract visitors regardless of competition. Even some of the great cultural World Heritage sites such as the Acropolis or the Pyramids, or tourism cities such as Venice and Florence, have lost much of their attractiveness through urban encroachment, pollution and overcrowding (National Geographic, 2006). A relatively minor beach tourism destination such as Byron Bay is constantly in competition with other beach tourism destinations at all scales. Competitors include: neighbouring NSW shires such as Tweed and Coffs Harbour; established beach tourism towns such as Queensland's Gold Coast; and international beach tourism destinations such as those in Europe, the Caribbean and South-East Asia. Competition with these destinations depends on the balance between the price and the perceived quality of the tourism product, in the eyes of potential purchasers and packagers.

Because of the restrictions on new supply of tourist accommodation, and proposed reductions in existing supply through barriers to holiday letting, tourist accommodation prices in Byron are higher than in competing destinations, for a similar quality of accommodation. This is true even at the backpacker end of the market: a bed in a backpacker place at Byron can cost more than a motel room on the Gold Coast. At the same time, the image that Byron Bay projects in both domestic and international tourist markets is as a New Age backpacker party 
town (Anon, 2006a): what Campbell (2006) refers to as "the area's reputation for barmy spirituality". This image is accentuated by two annual music festivals. Similar festivals are held across the border in Queensland's Gold Coast and Brisbane, but since those towns have much larger populations than Byron, they attract mainly local residents.

Several analyses (Loker-Murphy and Pearce, 1995; Australia, Bureau of Tourism Research, 2000; Laesser and Crouch, 2000) have indeed demonstrated that backpackers visiting Australia from overseas have relatively high total average per capita expenditure; but this is because they stay in Australia for much longer than most other types of tourist. Average expenditure per day, not surprisingly, is relatively low; and backpackers only stay in Byron, or anywhere else, for a few days. By discouraging the family market with higher daily expenditure, therefore, Byron's image as a backpacker destination does a disservice to its tourist industry.

Byron can also be a relatively unfriendly place for family tourists. The majority of Byron locals are no different from any other east Australian coastal town, interacting with tourists mainly through the various retail industries such as restaurants, souvenir shops, supermarkets, entertainment venues, local tours and so on. In addition to these "mainstream" locals, however, there is a conspicuous subsidiary culture whose members interact with tourists in a very different way. Members of this group tend to assume a stereotypical appearance, a staged representation of so-called hippy styles popular in the 1970s. Whilst purporting to dislike and despise tourists, they simultaneously attempt to profit from them, including various forms of panhandling. Similar groups, incidentally, use similar approaches at particular sites on Queensland's Gold Coast; but they are localised and inconspicuous, whereas in Byron they are a conspicuous feature of the town centre.

One prominent visitor is quoted as referring to "anti-tourist attitude" in Byron Bay, adding that "anti-tourist attacks" were common (ByronBaynow.com, 2006). The "counterculture" locals are generally harmless enough, and may even form part of the tourist attraction for visiting backpackers. They can, however, be quite off-putting to the majority of tourists with families or more mainstream cultural sensibilities, and these groups therefore favour more tourist-friendly coastal destinations such as Noosa north of Brisbane, or Coffs Harbour somewhat south of Byron Bay. Even places such as Pottsville in neighbouring Tweed Shire on the northern NSW coast, until recently a tiny and largely unvisited village, are rapidly overtaking Byron as a pleasant place for visiting tourists. 
There are some quite remarkable similarities with many tourism destinations in developing countries, where particular locals are both envious of tourists and keen to take their money through a variety of mechanisms, including staged cultural displays (Mowforth and Munt, 1998; Harrison, 2001). This, however, is beyond the scope of the current contribution.

Upturns and downturns in tourist numbers and expenditure, and in property sales and prices, can rarely be attributed reliably to any single factor. Factors such as housing cycles and petroleum prices affect many different destinations at once. Property prices in Byron, especially in prime beachfront suburbs, have continued to climb despite the very unfavourable planning and development context. According to local property dealers, however, the number of sales has fallen off sharply over the last two years, largely because purchasers are waiting for changes in local Government (Anon, 2006j).

Tourism income seems to have fallen more dramatically. Auditable data on tourism expenditure at such a localised scale, especially over rather short time periods, are not routinely available. Data collected by Australia's federal tourism agency are at coarse resolution. In addition, a very significant proportion of visitors stay in holiday rental houses where arrangements are made privately, either through real estate agencies or directly with the owners. These visitors do not show up in tourism statistics, and neither the rental transactions nor associated retail purchasers are counted as tourism expenditures. The most direct and immediate evidence on the decline in tourism derives directly from local Byron businesses, and their views have been expressed in a series of letters to the two local newspapers. These letters also show that, at least in the perception of these businesses, blame for the decline can be assigned to the actions of the LGA.

An editorial in late 2005 entitled "Business owners not happy ...." (Anon, 2005), refers to the "anti-tourism stance" of the Byron Shire Mayor, noting that "anyone who owned a business in town had been adversely affected .....". In early 2006, a local resident wrote that the Mayor "is trying to keep the tourists out of Byron but the fact is, we need them" (Beaumont, 2006). And in March 2006, an editorial entitled "Mayor's stance 'wrong"" said that according to a spokesman for the Holiday Letting Organisation, it seemed that the Mayor "was bent on destroying the Byron economy" (Anon, 2006k). These claims were later denied by the Mayor (Anon, 20061). In September 2006, however, residents were still writing that 
"the Shire has only one big industry left, tourism. This Council is doing its best to wreck it" (Narracott, 2006b).

There has been particular criticism of the 2006 Draft Local Environmental Plan, which is the planning instrument by which the Council seeks to convert its policies on oceanfront residential housing and holiday letting into legal development controls. The LEP seems to have been criticised by all stakeholders, business and conservation groups alike (Anon, 2006m; BEACON, 2006; Chigwidden, 2006d; Narracott, 2006c; Pugh, 2006; Tardif, 2006; Vaughan, 2006). According to Narracott (2006b), the Byron Shire Council has tried to "make welfare our number one industry"; and if the LEP were to be approved, the Byron economy would collapse and everyone would leave. According to Vaughan (2006) "what this LEP actually does is downzone virtually the entire urban area of Byron Bay to single dwelling status, full stop... If the Greens manage to slip it [the LEP] past Minister Sartor because of some sneaky political preference votes deal they have with ALP [Australian Labour Party] head office, it will have to be repealed very quickly."

According to Thalmaan (2006b), "Byron should have no problem picking-up the trophies for "worst managed" plus "most restricted Shire in the Commonwealth". A letter from the Hinterland part of Byron Shire, far from the oceanfront, says that any business people unhappy with Council should leave the Shire (Scott, 2006); whereas a resident at Belongil (Campbell, 2006) opines that: "We seem to be drowning in a confusing sea of hyperbole, rash comment, opinion and sheer off-the-face verbal effrontery."

Regardless of political stance, almost all the correspondents acknowledged the importance of tourism to the Byron economy. Cohen (2006), who wants "local only, tourist no go residential zones", also acknowledges "We are a tourist shire". Scott (2006), who wants business people to leave, still acknowledges that Byron "gets a very good share of the tourist dollar". Heilpern (2006), representing the local Green Party, refers to "the big tourist buck" Luke (2006), referring to tourism, says "let the money stay in Byron". The Mayor, quoted in an editorial (Anon, 2006b) referred to "the importance of tourism to the area". Harrison (2006), who complained about "Theme Park Byron", also referred in the same paragraph to “Tourist Destination Byron”. Narracott (2006d) says that Byron's "number one industry is tourism". 
In the early part of 2006 there were numerous calls for the Draft LEP to be abandoned (Anon, 2006m,n). There were also calls for public hearings (Anon 2006n; Tardif, 2006), but these went unheeded. A Council vote in the absence of one green-bloc Councillor, led to the shelving of the Draft LEP, in favour of a new LEP which fits the NSW State template (Burmester, 2006; Patterson, 2006a). Whilst one of Byron's two newspapers referred to this as "welcome news" (Burmester, 2006), the other was highly critical (Anon, 2006p). Both these newspapers, incidentally, have rather similar structures; about one fifth property and supermarket advertisements, one fifth TV, sports and entertainment guides; one fifth classified and paid political advertisements; $15 \%$ local news; and the remainder made up of notices, letters, editorials and articles. A motion to rescind the recent decision was tabled at the August 2006 Council meeting (Patterson, 2006a; Byron Shire Council, 2006) but apparently did not succeed (Anon, 2006h). As of late September 2006, it appears that the 2000 Draft LEP has been abandoned and a new LEP will be drafted over the next two years (Chigwidden, 2006b).

\section{Conclusions}

As with any process involving politics, many parts of the picture are hidden, and cause and effect can be difficult to unravel. The science is published if somewhat politicised; the planning instruments are foolish but documented; the perspectives and perceptions of at least some of the stakeholders are recorded; and the reductions in tourist expenditure, and consequences for businesses dependent upon it, are acknowledged by all.

Connecting the various components into a coherent picture is more complex, because the motives of the green-bloc Councillors and the local group BEACON are very difficult to discern (Buckley, 2004). All kinds of motives have been suggested, from secret individual vendettas to vote-trading in state elections, irrational ideologies to personal jealousies, well-intentioned ignorance to complex conspiracies by pseudo-religious cults. Similarly, various potential solutions have been suggested, such as: subsuming or dividing Byron into neighbouring Shires (Thalmaan, 2006b); the direct takeover of development approval by the State Government Minister for Planning; rate revolts by landowners and business people; and so on. These, however, are beyond the scope of this analysis.

From the perspective of tourism and climate change, the critical links are as follows. Because of social and political history in the area, a local government election system with 
vote reallocation, and a Mayoral casting vote, the local government in Australia's Byron Shire is controlled by a voting bloc with: a "green" or "progressive" label; a pseudo-sustainability ideology; and practical policies strongly opposed to property development, tourism, amenity migration, local population growth, and the majority of businesses.

Actual sealevel rise associated with anthropogenic climate change, both past and future, is no different at Byron Bay than anywhere else on central east-coast Australia. Projections for the rate of sealevel rise for this region are below the global average. The tidal range is small and wave energy low except during occasional storms. Compared with most of the world, real risks from rising sealevel at Byron are low. Projected rises within the next century can readily be addressed through straightforward engineering approaches which are already in wide and successful use in neighbouring coastal areas.

Sand transport along the principal town beach at Byron Bay has been modified severely in the past through construction of an artificial headland and groyne in the town centre, which has caused sand accretion on the updrift side, and erosion on the downdrift side, Belongil Beach. Perhaps for fear of potential public costs, both the local government and to a lesser degree the State Government have continually tried to deny this. Instead, they have adopted a series of planning instruments and development decisions which place very severe restrictions on oceanfront properties in the suburb of Belongil. Most recent and wide-ranging of these is a newly-introduced Draft Local Environmental Plan, currently abandoned but referred to in a very recent Court case (van Haandel vs Byron Shire Council 2006).

Byron Shire Council's policies in regard to tourism and property, especially in relation to Belongil, and including the draft LEP, are strongly opposed by the business community including property agents and the tourism industry, and also by residents within the Byron urban area. The only support seems to come from some residents in the hinterland area, and a small local lobby group which seems to have strong personal ties with individual Councillors.

Both the Local Government voting bloc and its supporting lobby group claim, quite erroneously, that Belongil Beach is at particular risk from rising sealevels and that this justifies their policies. This is simply not correct. 
The economic and social impacts of this controversy, based on misperceptions and misrepresentations of climate change, have already been very considerable. There have been particularly strong effects on the tourism and property industries, and flow-on effects for the entire Byron economy. Because of uncertainties over planning, investors have simply moved to neighbouring shires, especially Tweed to the immediate north. Tourist accommodation at Byron continues to shrink in supply, and tourists are increasingly put off by rising prices.

In addition, certain local residents who apparently believe the misinformation circulated by local political and lobby groups, seem to act aggressively towards tourists and sometimes business people, and this can creates a rather unfriendly atmosphere which further deters tourists, especially the higher-spending and family visitors.

Precisely the same real risks from potential sealevel rise exist in neighbouring areas in northern NSW and southeast Qld, but local governments in those areas have assessed those risks rationally and adopted appropriate planning controls. Broadly, they have required private property owners to protect their own land and dwellings through specified engineering measures, and they have funded works to protect public lands. It is only in Byron Shire that the risks from potential sealevel rise have been so wildly misrepresented, with negative consequences for the tourism industry. The reasons for such misrepresentation may be ideological, or they may be an attempt to avoid the consequences of impacts on private property caused by a public structure, namely the artificial headland and groyne in the town centre.

From a technical and economic perspective it would be remarkably easy to resolve the controversy, allow the Belongil landowners to protect their properties, restore investor confidence and re-establish a successful tourism industry, with both social and environmental as well as economic gains. It is only political power plays which prevent this at present.

\section{Acknowledgements}

My thanks to Professor Rodger Tomlinson of the Gold Coast Centre for Coastal Management for checking section on coastal processes, engineering and sealevel rise. Thanks also for valuable discussions with a number of Rodger's colleagues. Leads into the literature of political ecology were kindly provided by the Editor and two anonymous referees. 
REFERENCES

Anon. 2005. Business owners not happy Jan. Byron Shire News, 16 November 2005.

Anon, 2006a. An eye on the future of Byron Bay. Byron Shire Echo, 8 August 2006, p. 17.

Anon. 2006b. Search launched for new Byron hospital site. Byron Shire Echo, 25 April 2006, p. 1.

Anon, 2006c. Supa IGA. It's modern. It's big. It's bright. It's clean. It's Byron. Byron Shire Echo, 25 April 2006, p. 6.

Anon. 2006d. A tighter fist on planning. Byron Shire Echo, 14 March 2006, p. 8.

Anon. 2006e. BEACON slams Sartor on Becton delay. Byron Shire Echo, 2 May 2006, p. 5.

Anon. 2006f. Lazarus settles out of court. Byron Shire News, 22 June 2006, p. 2.

Anon. 2006gm. Fight is not over, opponents warn. Byron Shire News, 7 September 2006, p. 2.

Anon. 2006h. Westheimer opts for shirewide LEP. Byron Shire Echo, 15 April 2006, pp. 1-2.

Anon. 2006j. Optimistic view for real estate market. Byron Shire News, 15 June 2006. p. 24.

Anon. 2006k. Mayor’s stance ‘wrong’. Byron Shire News, 30 March 2006, p. 3.

Anon. 20061. Anti-business claims rejected by Mayor. Byron Shire News, 11 May 2006, p. 10.

Anon. 2006m. Abandon draft LEP: chamber. Byron Shire News, 16 March 2006, p. 1.

Anon. 2006n. Bay LEP hits new hurdle. Byron Shire News, 30 March 2006, p. 1.

Anon. 2006p. Due process denied. Byron Shire Echo, 4 July 2006, p. 8. 
Australia, Bureau of Tourism Research. 2000. Backpacker Visitors in Australia. 1997-1999. http//www.btr.gov.au/statistics/datacard/backpackers.html

Australia, Department of Environment and Heritage. 2006. Central Eastern Rainforest reserves (Australia). http://www.deh.gov.au/heritage/worldheritage/sites/cerra/index.html Accessed 18 September 2006.

BEACON (Byron Environmental and Conservation Organisation). 2004. President's Report to AGM. BEACON, Byron Bay.

BEACON (Byron Environmental and Conservation Organisation) 2006. LEP to drown Byron in flood of development, traffic and sewerage. Byron Shire Echo, 21 March 2006, p. 15.

Beaumont, L. 2006. T-shirt protest over LEP. Byron Shire Echo.

Boothroyd, P. 1995. Policy assessment. In Vanclay, F., and Bronstein, D. (eds). Environmental and Social Impact Assessment, 83-128. Wiley, New York.

Buckley, R. C. 2004. Legal minefield in long battle for Byron. The Australian, 25 March 2004, p. 52.

Burbidge, N. 1960. The phytogeography of the Australian region. Australian Journal of Botany, 8: 75-211.

Burmester, J. 2006. LEP back on agenda. Byron Shire News, 6 July 2006, p. 2.

Burnley, I. and Murphy, P. 2003. Sea Change: Movement from Metropolitan to Arcadian Australia. UNSW Press, Sydney. 272 pp.

Byron-bay.com, 2006. General Information. http://www.byron-bay.com/byronbay/general Accessed 12 July 2006.

ByronBayNow.com 2006. Byron Bay Australia. http://www.byronbaynow.com Accessed 12 July 2006. 
Byron Bay Online. 2006. Byron Bay Online Guide. http://www.byronbayonline.com.au Accessed 12 July 2006.

Byron Shire Council. 2004a,b. Resolutions 04-1056, 04-1057 of 21 December 2004. BSC, Mullumbimby.

Byron Shire Council. 2006. Byron Shire Council. www.byron.nsw.gov.au. Accessed 15 September 2006.

Campbell, B. 2006. LEP confusion. Byron Shire News, 30 March 2006, p. 33.

Campbell, J. 2006. Life's little penalties wake me up at night. Byron Shire Echo, 4 July 2006, p. 13.

Chigwidden, G. 2006a. Council must cop some blame. Byron Shire News, 7 September 2006, p.8.

Chigwidden, G. 2006b. Draft Byron Bay LEP now seems doomed. Byron Shire News, 17 August 2006, p. 1.

Chigwidden, G. 2006c. Van park residents not surprised by Govt action. Byron Shire News, 3 April 2006, p. 3.

Chigwidden, G. 2006d. Need for draft LEP public hearing. Byron Shire News, 6 April 2006, p. 8.

Cohen, I. 2006. The cultural cleansing of Byron Shire? Byron Shire Echo, 21 March 2006, p. 13.

Crime and Misconduct Commission Queensland 2006. Independence, Influence and Integrity in Local Government. CMC, Brisbane.

Dane, D. 2006. Dredging up sand and the Bay's NYE. Byron Shire Echo, 25 April 2006, p. 12. 
Douglas, B. C., Kearney, M. S., and Leatherman, S. P. 2001. Sea Level Rise: History and Consequences. Academic, San Diego.

Forsyth, T. 2003. Critical Political Ecology: the Politics of Environmental Science. Routledge, London.

Gilet, D. 2006. Untitled letter. Byron Shire Echo, 2 May 2006, p. 13.

George, T. et 52 al. 2006. Open letter to Mr Sartor, Byron Shire Echo, 21 March 2006, p. 4.

Gold Coast City Council. 2006. Gold Coast City Council. http://www.goldcoast.qld.gov.au Accessed 15 September 2006.

Gold Coast and Hinterland Environment Council. 2006. Welcome to the home page of Gecko. http://www.gecko.org.au/

Goodwin, I. D. 2005. A mid-shelf, mean wave direction climatology for southeastern Australia, and its relationship to the El Niño - Southern Oscillation since 1878 A.D. International Journal of Climatology, 25: 1715-1729.

Goodwin, I. D. 2006. Review of Long-Term Coastal Behaviour, Climate Change and Coastline Hazard Definition for Belongil - Byron Bay, NSW. The University of Newcastle Research Associates, Newcastle Australia.

Goodwin, I. D., Stables, M. A. and Olley, J. M. 2006. Wave climate, sand budget and shoreline alignment evolution of the Iluka-Woody Bay sand barrier, northern New South Wales, Australia, since 3000 yr BP. Marine Geology, 226: 127-144.

Gordon, A. D., Lord, D. B. and Nolan, M. W. 1978. Byron Bay - Hastings Point Erosion Study. Report No. PWD 78026. NSW Department of Public Works, Sydney. 228 pp.

Gössling, S. (ed.) 2003. Tourism and Development in Tropical Islands: Political Ecology Perspectives. Edward Elgar, Cheltenham. 304 pp.

Grenfell, R. 2006. Get creative. Byron Shire Echo, 25 April 2006, p. 10. 
Hall, A. 2006a. Beachfronters. Byron Shire Echo, 15 August 2006, p. 11.

Hall, A. 2006b. Untitled letter. Byron Shire Echo, 25 April 2006, p. 12.

Harrison, D. (ed). 2001. Tourism and the Less Developed World - Issues and Case Studies. CABI, Wallingford, UK.

Harrison, R. 2006. For Art's sake. Byron Shire Echo, 27 June 2006, p. 10.

Haworth, R. J., Baker, R.G.V., Flood, P. G., 2002. Predicted and observed Holocene sea-levels on the Australian coast: what do they indicate about hydro-isostatic models in far-field sites? Journal of Quaternary Science, 17: 581-591.

Heilpern, S. 2006. Untitled letter. Byron Shire Echo, 8 August 2006, p. 13.

Hudson, T. 2006. Untitled letter. Byron Shire Echo, 8 August 2006, p. 13.

Intergovernmental Panel on Climate Change, 2007. Fourth Assessment Report. (In press).

Johnson, J. 2003. Moving closer to heaven: growth and change in the Greeater Yellowstone Region, USA. In : Buckley, R.C., Pickering, C.M. and Weaver, D.B. (eds.), Nature-Based Tourism, Environment and Land Management, 77-88. CABI, Wallingford.

Laesser, C., and Crouch, G. I. 2006. Segmenting markets by travel expenditure patterns: the case of international visitors to Australia. Journal of Travel Research, 44: 397-406.

Loker-Murphy, L. and Pearce, P. L. 1995. Young budget travels: backpackers in Australia. Annals of Tourism Research, 22: 819-843.

Luke, M. 2006. Untitled letter. Byron Shire Echo, 15 August 2006, p. 10.

McDonald, M. 2006. Byron LEP saga drags on. Byron Shire Echo, 29 April 2006, p.15. 
McDonald, M. 2006a. North Beach gets the nod. Byron Shire Echo, 5 September 2006, pp. 1-2.

Miller, L. and Douglas, B. 2006. On the rate and causes of twentieth century sea-level rise. Philosophical Transactions of the Royal Society A: Mathematical, Physical and Engineering Sciences, 364: 805-820.

Mowforth, M., and Munt, I. 1998. Tourism and Sustainability. Routledge, London. 363 pp.

Narracott, T. 2006a. Untitled letter. Byron Shire Echo, 8 August 2006, p. 13.

Narracott, A. 2006b. Untitled letter. Byron Shire Echo, 21 March 2006, p. 13.

Narracott, T. 2006c. Byron in crisis. Byron Shire Echo, 27 June 2006, p. 10.

Narracott, T. 2006d. Pretend LEP. Byron Shire News, 6 April 2006, p. 8.

National Geographic. 2006. Destination Sustainability Survey 2006. In Press.

Overpeck, J. T., Otto-Bliesner, B. L., Miller, G. H., Alley, R. B., Muhs, D. R. and Marshall, S. J. 2006. Response. Science, 313: 1044-1045.

Patterson, L. 2006a. Council changes Byron Bay LEP. Byron Shire Echo, 4 July 2006, pp. 1-2.

Patterson, L. 2006b. State grabs park power from Byron Council. Byron Shire Echo, 1 August 2006, p. 1.

Pugh, D. 2006. Global warming's warning for estuaries. Byron Shire Echo, 25 April 2006, p. 14.

Robbins, P. 2004. Political Ecology: a Critical Introduction. Blackwell, Malden Mass.

Roth, R. 2006. Reviews: Political ecology: a critical introduction. Canadian Geographer, 50: $135-136$. 
Roy, P. S., Stephens, A. W. and Gordon, A. D. 1978. Quaternary Geology and Sediment Budget for the Byron Bay Region, Eastern Australia. NSW Geological Survey Report No. GS1978/276. NSW Department of Mines, Sydney.

Schiermeier, Q. 2006. A sea change (editorial). Nature, 439: 256-260.

Scott, G. 2006. Untitled letter. Byron Shire Echo, 21 March 2006, p. 13.

Scott, P. and Sullivan, S. (eds). 2000. Political Ecology: Science, Myth and Power. Arnold, London.

Short, A. 1999. Handbook of Beach and Shoreface Morphodynamics. Wiley, Sydney.

Tabart, T. 2006. Untitled letter. Byron Shire Echo, 8 August 2006, p. 13.

Tardif, R. 2006. Beyond rescue. Byron Shire News, 6 April 2006, p.8.

Thalmaan, R. 2006a. Time to act. Byron Shire News, 11 August 2006, p. 8.

Thalmaan, R. 2006b. 'Divorce' needed. Byron Shire News, 6 April 2006, p. 9.

Thom, B. 2003. Beach protection in NSW. Environment and Planning Law Journal, 20: $325-358$.

van Haandel, John v. Byron Shire Council, 2006. Land and Environment Court of NSW, No. 10734 of 2005. Land and Environment Court, Sydney.

Vaughan, J. 2006. Untitled letter. Byron Shire Echo, 21 March 2006, p. 13.

Walsh, K.J.E., Betts, H., Church, J., Pittock, A. B., McInnes, K. L., Jackett, D. R., and McDougall, T. J. 2004. Using sea level rise projections for urban planning in Australia. Journal of Coastal Research, 20: . 586-598.

Watson, P. 2003a,b,c. Re: Peer Review Byron Shire Coastline Management Study. Letters to Byron Shire Council, 25 February 2003, 2 July 2003, 27 November 2003 from NSW Department of Infrastructure, Planning and Natural Resources, Sydney. 
WBM Oceanics, 2003. Byron Coastline Management Study. WBM Oceanics, Brisbane.

Westerhausen, K. and Macbeth, J. 2003. Backpackers and empowered local communities: natural allies in the struggle for sustainability and local control. Tourism Geographies 5: 71-86.

Witze, A. 2006. Meteorology: bad weather ahead. Nature 441: 564-566.

Zhang, K. Q., Douglas, B. C. and Leatherman, S. P. 2004. Global warming and coastal erosion. Climatic Change 64: 41-58. 